\title{
The hitchhiker's guide to TUPE and pensions
}

\author{
Received: 1st June, 2005
}

\section{Scott Moncur}

joined Harper Macleod as a partner in March 2004. He qualified as a solicitor in 1991 and was accredited by the Law Society of Scotland as a pension specialist in 1999. He is a member of the Law Society of Scotland Pension Law Subcommittee.

\begin{abstract}
This paper provides a summary of the combined effects of the application of Transfer of Undertakings (Protection of Employment) Regulations 1981 (TUPE) and pension protection regulations after 6th April, 2005 on business asset transfers involving employees.
\end{abstract}

Keywords: transfers; bulk; business; assets; employee; pension

\section{Introduction}

The business of pensions will be subjected to seismic shifts over the next year or so. Not only is the UK tax framework being altered, but the true costs of pension provision is being made clear by Adair Turner, and numerous FRS17 reports. This means business will be subject to change.

This paper focuses on one pension change that has already happened that directly affects the buying and selling of businesses: Transfer of Undertakings (Protection of Employment) Regulations 1981 (TUPE) and pensions. Glibly, many have assumed that pensions are excluded from TUPE protection (ie worker's terms and conditions in relation to pensions are not protected under TUPE), but this is now never going to be the case. This paper sets out the implications of two European case reports concerning TUPE in relation to rights that transfer under occupational pension schemes, and the Transfer of Undertakings (Pension Protection) Regulations 2005.

\section{EC Directive and Pension Schemes Act 1993}

The European Community is the source of TUPE. It seems a long time since 1977, when Council Directive 77/187/EEC of 14 February was passed. This Valentines Day legislation has been interpreted and amended (see Council Directive 98/50/EC) ever since then. Directive 2001/23/EC now sets out the obligations on business transfers that member states (ie governments) have to implement. Article 3 of that Directive, particularly paragraphs $4(a)$ and (b), is the starting point of any discussion. The UK government has consistently argued that accrued rights protection is adequately dealt with by the Pension Schemes Act 1993, Part IV: Protection of Early Leavers. It is only with the new 2005 Regulations that future rights are explicitly addressed for non-public sector transfers.

It is interesting to note that as a matter of policy, the government imposes much more stringent requirements for 
future pension rights (ie Fair Deal for Pensions, Government Actuaries

Department, June 2004).

TUPE applies to the situation where there is a transfer of an undertaking, ie a business, from one entity to another (a 'relevant transfer'). The Regulations provide that the terms and conditions of employment of the employees working in the undertaking are transferred from the old employer to the new employer at the time the relevant transfer takes place. There is an exemption from this for terms of employment, which relates to occupational pension schemes but this exemption is only applicable to occupational pension schemes to the extent that the benefits thereunder relate to old age, invalidity or survivors of the employee. This exemption, at least in words, is carried through in the drafts of the rewrite due to be in place later this year.

\section{So where is the current complexity?}

This paper will begin with some case law.

The first case to look to is Beckmann $v$ Dynamco Whicheloe MacFarlane Limited (2002) 64 PBLR.

$B$ worked for a health authority and the undertaking she worked for was transferred and TUPE applied. B was a member of the NHS superannuation scheme and the standard terms of employment for NHS workers provided that where an employee is made redundant between age 50 and the normal retirement age, special benefits through the pension scheme applied:

(a) an early retirement pension, based upon actual years of pensionable service, paid from the date of redundancy to the normal retirement age; (b) the grant of credit for additional years of service where appropriate;

(c) a lump sum compensation payment of three times the annual allowance; and

(d) early payment of a lump sum normally paid on retirement.

B was made redundant after she turned 50 but did not receive these benefits. It was argued that as the scheme was an occupational pension scheme, the benefits did not transfer under TUPE.

The European Court of Justice (ECJ) held that these benefits were not old age, invalidity or survivor's benefits, since they applied on a redundancy prior to normal retirement. Accordingly, these benefits did not fall within the exemption under TUPE and should have been provided after transfer.

The second case is Martin $v$ South Bank University (2003) PLR 329.

In this case lecturers at an NHS training college were entitled to benefits under the NHS superannuation arrangements including enhanced benefits on early retirement between 50 and normal retirement age if they were dismissed by reason of redundancy, or took voluntary early retirement following an organisational change, or took early retirement 'in the interests of efficiency of the service'.

The college became part of South Bank University and the lecturers joined the Teacher's Superannuation Scheme which provided less favourable benefits. In particular, the university, as employer could decide whether or not to pay the benefits on early retirement and how much it should pay. If the university decided to pay the benefits, it had to meet the costs by means of additional contributions to the scheme.

Three lecturers made a complaint to an employment tribunal that the university should provide them with 
early retirement benefits which were as good as they were previously entitled to and the case was referred to the ECJ.

The ECJ distinguished between early retirement and the departure of an employee at the end of his normal working life as laid down by the general structure of the pension scheme of which he or she is a member. Benefits on the end of his normal working life ("normal retirement') would presumably be regarded as 'old age' benefits within the exclusion from protection under TUPE. Other benefits paid earlier than normal retirement were protected by TUPE. As a result, the court held that the transferee had a duty to ensure the employees were accorded early retirement on the terms under which they were entitled to under the transferor employee.

It does not take long to realise this leads to logical inconsistencies when comparing schemes and industry practice. The rights of employees will be determined by the normal retirement date of their scheme. This means that a purchaser has to examine the transferors pension scheme before coming to a decision. There are practical issues where the early retirement right is not an absolute, and is either subject to a discretion of the scheme trustees or discretion and consent of employer. How much is the transferee bound by the historic usage of discretion or consent? More particularly, what value should be passed from the pension scheme of the transferor to that of the transferee that accurately reflects the protected benefit? In practice the issue is accommodated in terms of a particular deal, but it is not easy to draw principals of guidance from the case law.

The government is currently in the process of consulting on draft amendments to the 1981 TUPE Regulations, which are expected to come into force in October 2005. The current consultation paper explicitly refers to the ECJ's decisions in the Beckmann and Martin cases. It states that these decisions are consistent with the government's own view of the intended effect of the 1981 Regulations. This position helps one understand why the government has been so keen to promote 'Fair Deal for Staff: Pension Procurement of Bulk Transfer Agreements and Related Issues' (published June 2004).

So, the provision relating to pensions in the draft version of the revised Regulations has therefore remained the same, and the Beckmann and Martin decisions are to remain the definitive statement of the application of the TUPE Regulations on 'non'-old age pension benefit.

\section{European case law and business costs}

What does this mean for business? When buying a business that has any type of pension arrangement, great care is required in establishing what constitutes benefits relating to old age, invalidity and survivor's benefits. If there are early retirement benefits, a decision has to be taken on what to do for the employees' rights to these early retirement pensions in the future. This decision may affect the price to be paid for the business, or involve transfers of transferring employees' entitlement to the purchaser's pension arrangements.

Unsurprisingly, the safest response in law for a purchaser to Beckmann and Martin is expensive and not too flexible. Creative thought and excellent communication are needed to effect a working response for business.

This is a particularly emotive area to address in a business purchase as the risks are contingent on events usually controlled by the purchaser, and 
Table 1: A pension scheme ready reckoner

\begin{tabular}{|c|c|}
\hline Type of scheme & Need to pay or provide \\
\hline Occupational money purchase pension scheme & Need to pay 'relevant contributions' \\
\hline Occupational final salary pension scheme & $\begin{array}{l}\text { Need to provide: } \\
\text { - benefits which are valued at not less than six per } \\
\text { cent of pensionable pay (as defined in the } \\
\text { scheme rules) for each year of employment. } \\
\text { Transferring employees to pay not more than six } \\
\text { per cent of pensionable pay into the scheme; or } \\
\text { - reference scheme benefits; or } \\
\text { - 'relevant contributions' }\end{array}$ \\
\hline Group PP or stakeholder & Need to pay 'relevant contributions' \\
\hline Individual pensions & Need to pay 'relevant contributions' \\
\hline
\end{tabular}

government initiatives are increasing employees' awareness of their (lack of) pension entitlement. The impact of these decisions has not been addressed by the new Pension Protection Regulations.

\section{Transfers of Employment (Pension Protection) Regulations 2005 ('the 2005 Regulations')}

The government decided not to have all the TUPE regulations in one Regulation. Pension protection is not dealt with in the main TUPE regulations. It is dealt with separately under the Pensions Act 2004 and relevant regulation. These are the 2005 Regulations. The government published the 2005 Regulations on 17th March, 2005, a whole three weeks before they became effective.

The courts will inevitably be required to rule on the interpretation of the 2005 Regulations as they are not as straightforward as a first read may suggest. In the meantime, a business has to have some practical advice on what it needs to do.

The 2005 Regulations apply to:

- purchases of business (not shares) where the TUPE Regulations apply; and

- where the vendor operated any occupational pension scheme; or

- the vendor contributed to a personal pension or stakeholder scheme; and

- in all cases completion of the purchase is after 5th April, 2005.

They require a purchaser to offer to those transferring employees who are members of the vendor's scheme or would have been eligible, access to a pension scheme of the purchaser's choice. As a ready reckoner, the purchaser has to offer one or more of the types of pension scheme and contributions listed below.

Some definitions are always useful:

(a) 'Relevant contributions' are:

- if an employee contribution is less than six per cent of remuneration paid to him, an amount at least equal to that contribution; or

- if an employee contribution is more than six per cent of remuneration paid to him, an amount at least equal to six per cent.

(b) 'remuneration' is basic pay.

\section{Future changes to contracts}

There has been difficulty in ascertaining when an employee's contract can be altered after a TUPE transfer. Thankfully there has been specific provision for this. The Pensions Act 2004 ('2004 Act') allows a purchaser and a transferring 
employee after the transfer to agree that there will be no obligations to provide a pension scheme or for the purchaser to contribute to it. This gives scope for some creativity.

\section{Application to business deals}

The areas most likely to cause problems are:

\section{Choice of purchaser's scheme}

The 2005 Regulations do not provide for who chooses what type of scheme is to be offered and they do not specify what is to happen if the purchaser already has one or more pension schemes in place. Should the transferring employees be members of that or another scheme? It is part of the transferring employee's contract that they receive something where the 2005 Regulations apply. To limit risk, one would have the employees agree in advance what they are to be offered as part of the consultation exercise. This is not always practical, so the decision that most reflects the current entitlement is often selected as a default.

If business purchases are anticipated, it might be worthwhile completing some preparatory work establishing what sort of scheme for transferring members should be offered before the transfer is completed.

The 2005 Regulations: Why - minima?

The 2005 Regulations specify the minimum a purchaser has to provide. Many will seek to work towards this. There is now scope to argue under the UK legislation and the European Directive that by specifying minima, the government intended the prescribed minima to be the easiest way to say that all future pension rights are to be protected (subject to subsequent amendment), without in fact stating it. If the government is insisting on a 'fair deal' for pensions for its own employees, it is an argument that has quite a degree of persuasion. The real question is who would be able to finance any such court action to prove full future pension rights should be protected? The press have reported on the case involving an employee of Fujitsu suing because he was moved from a final salary scheme to a money purchase scheme, so there may well be such a person or union willing and able to mount this challenge of TUPE.

\section{Early retirement rights}

Martin and Beckmann have not been dealt with by the 2005 Regulations. If the transferor has an early retirement programme of any sort, it should be investigated to discern whether it does or does not transfer, under the European case law. The age profiles of the transferring employees and the intention for future redundancy will influence how much of an issue this will be in any particular case. If there are rights that do transfer, this will increase the costs beyond the prescribed minimum.

The principal issue will be valuing the benefits to be protected and what a purchaser will be bound to provide. This will involve actuaries and lawyers working closely together to ascertain what the best way is to resolve everyone's concerns.

\section{Employee expectation}

There are three difficulties. The first is when transferring employees have better benefits than are protected by the 2005 Regulations minima. Anything less than the current provision will be understood by the employee as a cut in wages. The second is when current employees of the transferee/purchaser have different pension benefits than the transferring employees. Both situations will need to 
be managed, and decisions taken carefully communicated. Solutions will be determined by an employer's employment policy and attitude to cost, investment in employees and risk. The third point applies to money purchase schemes. If the money purchase benefits under the transferor/sellers scheme would have outperformed those in the transferee/purchaser's scheme, then there is the chance that someone will seek to prove that the transferee/purchaser took an investment decision.

This issue can be prevented by the transferee/purchaser taking financial advice. Separately the transferee/purchaser might take advantage of the government allowing financial advice up to $£ 150$ per employee to be given tax free to explain the consequences and the reasoning behind any decision taken.

\section{Interaction with current TUPE Regulations}

Confusion will arise here. From reading the TUPE Regulations, there is no clue about the 2005 Regulations. It is essential to read the 2005 Regulations with the 2004 Act and TUPE

Regulations and the European case law nearby. It is only with ready access to all these sources of law on this topic that a proper understanding can be had.

\section{The Business Purchase Agreement and pensions}

Where the 2005 Regulations apply, one really has to question who has an interest in prescribing what the purchaser provides on pensions. If the seller is to provide an undertaking to transferring value for pensions (by adjustment of price or direct payment) then one can understand that the seller would want in return for any value transferred a requirement for a prescribed level of benefit. A purchaser, however, would not particularly want to have onerous future pension rights prescribed in the business purchase agreement if there are final salary benefits pre- and post-transfer and pensionable service is to include pretransfer service.

\section{Summary}

Due diligence and employee communication will determine if it is significant enough a problem to affect the viability of the purchase

All things considered, the conclusion must be that pensions have to be considered even if to be dismissed. Pensions will give consistent trouble for all except the simplest personal pension schemes. It can only be hoped the far sightedness of the current minister for the DWP will bring clarity and, as importantly, certainty in the wake of the further pension reforms promised. One prediction that is safe to make is that this will not be the last paper on the subject!

(C) Scott Moncur 